\title{
Implication of time equation in mature and immature area of ramp using time driven activity-based costing
}

\author{
S.N.A.M. Zaini1.* and M.Y. Abu ${ }^{1}$ \\ ${ }^{1}$ Faculty of Manufacturing and Mechatronic Engineering Technology, Universiti Malaysia Pahang, 26600 Pahang, Malaysia.
}

\begin{abstract}
At present, $28 \%$ of world palm oil output and $33 \%$ of global exports are accounted by Malaysia. Malaysia has an important role in meeting the rising world demand for oils and fats in the long term as it is a largest producer and exporter of palm oil and palm oil products. In recent times, few problems have actually happened in this plantation which are difficult to establish a time equation for analyzing the variation of activities, the rate establishment is unsuitable to display the connection between resources supplied and the practical capacity and the manager does not have a method for monitoring capacity usage and unused capacity. The aim of this work is to develop the time equation of mature and immature area at ramp for a better accuracy. Time driven activitybased costing (TDABC) is implemented because the time is successfully measured, the idle capacity is correctly determined and the capacity used and the unused capacity are differently listed. This work considers a data in 2017 to develop the solution. This work found that in the mature area from the available capacity utilization, ramp has high unused capacity with 67492.80 min which means the resources should be forecast properly in future. Meanwhile in the immature area, ramp has closest value to the practical capacity with 6667.20 min and RM5667.12 which indicates the company properly utilizes their resources. Therefore, TDABC provides more comprehensive understanding of practical resources and its associated costs while measuring processes and encouraging quality improvement.
\end{abstract}

\section{ARTICLE HISTORY}

Revised: $26^{\text {th }}$ August 2020

Accepted: $30^{\text {th }}$ September 2020

\section{KEYWORDS}

Ramp,

palm oil plantation,

time-driven activity-

based costing,

capacity cost rate,

time equation.

\section{INTRODUCTION}

Numerous implementations of palm oil in food and non-food product lines are very well known mainly for their versatility. The globalization of the international economy has brought international issues in the areas of sustainable development to complex manufacturing and utilization patterns [1]. One of the largest source of oil marketed on the global economy among some of the 17 major fats and oils is palm oil. The industry makes a valuable contribution to the Gross Domestic Product (GDP), a national agricultural sector that produces an export revenue of RM 68,49 billion in 2018 [2].

Sustainable green practices service are very important to the management, quality control and organizational skills. It was somehow presented as a consequence of the lack of financial awareness and an improper cost structure. 3 As the direct work quality of the commodity decreased, traditional standard cost structures were much less advantageous until the 1980s [3]. Activity-based costing (ABC) is a costing methodology that has been formulated by Cooper and Kaplan who suggested that many products consume the same operations and require different levels of resources [4]. The expenses in products for production based on activity, selling or promoting goods are focused on the method [5]. The approach is therefore best suited for the business that regularly produces material in batches [6]. To each of the activities involved, they allocated real financial statements and right cost drivers and ultimately improved the company's profitability [7].

On the contrary, TDABC is a changed $\mathrm{ABC}$ that allocates costs of resources from cost objects specifically at the capacity cost rate. This approach is based on a fundamental that cost drivers are transformed into time equations that represent time required for carrying on a given activity [8]. [9] has demonstrated that the company has been provided with information about manufacturing costs and used time capacity, and has a chance to use TDABC to improve the precision in selecting the suitable process for each of the products. [10] found that over-used capacity with a number of under-used stations give a simple overview of the management of the organization for better investment strategies in the automotive sector. With the magnetic component analysis, [11] has verified the loss manufacturing costs of the winding toroid core is - RM 2967504.12 and the unused capacity is -889200.12 minutes which able to maximize the productivity 
of time. Therefore, [12] stated that TDABC is regarded to be the most robust and advanced method for calculating the use of resources usage and its unused capacity.

\section{RESEARCH METHODOLOGY}

The TDABC is enforced through all those phases. All activities and sub-activities are described as process mapping and all possible resources are structured. Then, time equation is constructed, which is directly proportionate to the cost driver of their activities. Capacity cost rate is discovered by an assessment of all capacity costs and the practical resources used during growth and development at this moment. Ultimately, the forecast is accomplished by calculating the unused capacity concerning time and cost. This work considered ramp as the activity center which consists of one activity namely ramping with three sub-activities such as grading, weighing and external transportation. By quantifying the frequency of activity in a month, the estimated capacity needed for each task was assessed. Through multiplying the duration of an activity by the time it was carried out, the total time it was invested can be identified.

\section{RESULTS}

The volumes of cost-drivers for the activity centers is shown in Table 1. In mature area, it required 77.26 rounds to cover 1545.2 acres with two cycles a month while in immature area, it required 54.56 rounds to cover 1091 acres. The trailer lorries used are able to carry 40 tons for each trip.

Table 1. Volume of cost-drivers for the ramp.

\begin{tabular}{|c|c|c|c|}
\hline Var. & Driver & $\begin{array}{r}\text { Quantity/month } \\
\text { (mature) }\end{array}$ & $\begin{array}{r}\text { Quantity/month } \\
\text { (immature) }\end{array}$ \\
\hline & Ramping & & \\
\hline $\mathrm{X}_{1}$ & Grading (rounds) & 77.26 & 54.56 \\
\hline $\mathrm{X}_{2}$ & Weighing (rounds) & 77.26 & 54.56 \\
\hline $\mathrm{X}_{3}$ & External transport (rounds) & 77.26 & 54.56 \\
\hline
\end{tabular}

In order to calculate the estimated time used, a time equation is necessary. Each activity 's estimated time was built on the theory of motion and time study. Each estimated time taken for sub-activities are same for both mature and immature areas. All sub-activities have the same time taken in each round, which is 240 minutes per round for mature area and 210 minutes per round for immature area. This is due to the activities that depend on the same factor which is number of trips made. If there are 20 rounds of trip made in grading for every month, so do in weighing the FFB and in external transportation. For each activity core, the TDABC time equation should include any time required for all subactivities within a single equation as mentioned in Table 2.

Table 2. Time equations for ramp

\begin{tabular}{clll}
\hline No. & Activity & Area & Time Equations \\
\hline 1. & Ramping & Mature & $240 \mathrm{X}_{1}+240 \mathrm{X}_{2}+240 \mathrm{X}_{3}$ \\
& & Immature & $210 \mathrm{X}_{1}+210 \mathrm{X}_{2}+210 \mathrm{X}_{3}$ \\
\hline
\end{tabular}

In Table 3, it shows on how to get the actual used capacity for sub-activities in all activity centers by multiplying the value of quantity or round needed for sub-activities per month with total time taken for every round. For mature area, the total used capacity is $55672.20 \mathrm{~min} / \mathrm{month}$ while for immature area is $34372.80 \mathrm{~min} / \mathrm{month}$.

Table 3. Total used time for sub-activities of ramp

\begin{tabular}{|c|c|c|c|c|c|c|c|}
\hline \multirow[t]{2}{*}{ Var. } & \multirow{2}{*}{$\begin{array}{c}\text { Driver } \\
\text { Area }\end{array}$} & \multicolumn{2}{|c|}{ Quantity/month } & \multicolumn{2}{|c|}{ Minute/round } & \multicolumn{2}{|c|}{$\begin{array}{l}\text { Used capacity } \\
\text { (min/month) }\end{array}$} \\
\hline & & Mature & Immature & Mature & Immature & Mature & Immature \\
\hline & Ramping & & & & & & \\
\hline $\mathrm{X}_{1}$ & Grading (rounds) & 77.26 & 54.56 & 240 & 210 & 18542.40 & 11457.60 \\
\hline $\mathrm{X}_{2}$ & Weighing (rounds) & 77.26 & 54.56 & 240 & 210 & 18542.40 & 11457.60 \\
\hline \multirow[t]{2}{*}{$\mathrm{X}_{3}$} & External transport (rounds) & 77.26 & 54.56 & 240 & 210 & 18542.40 & 11457.60 \\
\hline & Total: & 231.78 & 163.68 & 720 & 630 & 55672.20 & 34372.80 \\
\hline
\end{tabular}

The actual time spent (used capacity) of ramp in mature area $=(240 \times 77.26)+(240 \times 77.26)+(240 \times 77.26)$

$$
=55627.20 \text { minutes. }
$$

The actual time spent (used capacity) of ramp in immature area $=(210 \times 54.56)+(210 \times 54.56)+(210 \times 54.56)$

$$
=34372.80 \text { minutes. }
$$

For the practical capacity, working hours of employees are been estimated. The plantation's working hours are Monday to Saturday, 8 a.m. to 6 p.m. and on Sunday from 8 a.m. to 1 p.m. The employees work an average of eight hours a day for Monday to Saturday basis (26 days a month) and five hours on Sunday (4 days a month). The employees have 
an acceptable capacity of 13,680 minutes each per month. Table 4 summarizes the estimated expenses of all the resources used in these sub-activities.

Table 4. Resources costs within the ramp

\begin{tabular}{|c|c|c|c|c|c|c|c|}
\hline \multirow[t]{2}{*}{ No. } & \multirow[t]{2}{*}{ Sub-Activities } & \multicolumn{2}{|c|}{ Labor costs } & \multicolumn{2}{|c|}{ Overheads } & \multicolumn{2}{|c|}{$\begin{array}{c}\text { Cost of all resources } \\
\text { supplied }\end{array}$} \\
\hline & & Mature & Immature & Mature & Immature & Mature & Immature \\
\hline & Ramping & & & & & & \\
\hline 1. & Grading & 0 & 0 & 0 & 0 & 0 & 0 \\
\hline 2. & Weighing & 0 & 0 & 0 & 0 & 0 & 0 \\
\hline 3. & External Transportation & 9271.20 & 6546 & 40175.20 & 28366 & 49446.40 & 34912 \\
\hline & Total: & 9271.20 & 6546 & 40175.20 & 28366 & 49446.40 & 34912 \\
\hline
\end{tabular}

The capacity cost rate (RM per minute) can be obtained using the following Equation (1) and is shown in Table 5.

$$
\text { Capacity cost rate }=\frac{\text { Cost of all resources supplied }}{\text { Practical capacity }}
$$

Table 5. Capacity cost rate of each sub-activity for the activity center 3 - ramp

\begin{tabular}{|c|c|c|c|c|c|c|c|}
\hline \multirow[t]{2}{*}{ No. } & \multirow{2}{*}{$\begin{array}{l}\text { Sub-Activities } \\
\text { Area }\end{array}$} & \multicolumn{2}{|c|}{$\begin{array}{c}\text { Cost of all resources } \\
\text { supplied }\end{array}$} & \multicolumn{2}{|c|}{ Practical capacity } & \multicolumn{2}{|c|}{$\begin{array}{l}\text { Capacity cost rate } \\
(\mathrm{RM} / \mathrm{min})\end{array}$} \\
\hline & & Mature & Immature & Mature & Immature & Mature & Immature \\
\hline & Ramping & & & & & & \\
\hline 1. & Grading & 0 & 0 & 41040 & 13680 & 0 & 0 \\
\hline 2. & Weighing & 0 & 0 & 41040 & 13680 & 0 & 0 \\
\hline 3. & External Transportion & 49446.40 & 34912 & 41040 & 13680 & 1.20 & 2.55 \\
\hline & Total: & 49446.40 & 34912 & 123120 & 41040 & 0.40 & 0.85 \\
\hline
\end{tabular}

The CCR for external transportation in ramp for both mature and immature areas, which are 0.40 and 0.85 . Next, the overall utilization costs for each ramp sub-activity are shown in Table 6.

Table 6. Total production costs for ramp

\begin{tabular}{|c|c|c|c|c|c|c|}
\hline \multirow[t]{2}{*}{ Activities } & \multicolumn{2}{|c|}{$\begin{array}{l}\text { Used capacity } \\
\text { (min) }\end{array}$} & \multicolumn{2}{|c|}{$\begin{array}{c}\text { Capacity cost rate } \\
(\mathrm{RM} / \mathrm{min})\end{array}$} & \multicolumn{2}{|c|}{$\begin{array}{c}\text { Total cost } \\
(\mathrm{RM} / \mathrm{month})\end{array}$} \\
\hline & Mature & Immature & Mature & Immature & Mature & Immature \\
\hline Ramp & & & & & & \\
\hline Ramping & 55672.20 & 34372.80 & 0.40 & 0.85 & 22250.88 & 29216.88 \\
\hline Total: & 55672.20 & 34372.80 & & & 22250.88 & 29216.88 \\
\hline
\end{tabular}

\section{DISCUSSION}

Figure 1 shows no insufficient capacity in terms of time and cost. The unused capacity in mature area shows much higher which is 67492.80 minutes which results to waste cost of RM26997.12, compared to unused time (6667.20 minutes) in immature area which caused RM5667.12 to loss. The practical capacity provided is exceeding the necessity. The influences to this effect can only be as the number of FFB reduces or rises from the general sum taken each cycle. This is due to the fact that the ramp's sub-activities which grade, weigh and transport FFB to mill completely comply with a standardized schedule. The number of trips for each sub-activity is correlated with this, as well as the resources expenses and practical capacity are focused on this basis. 


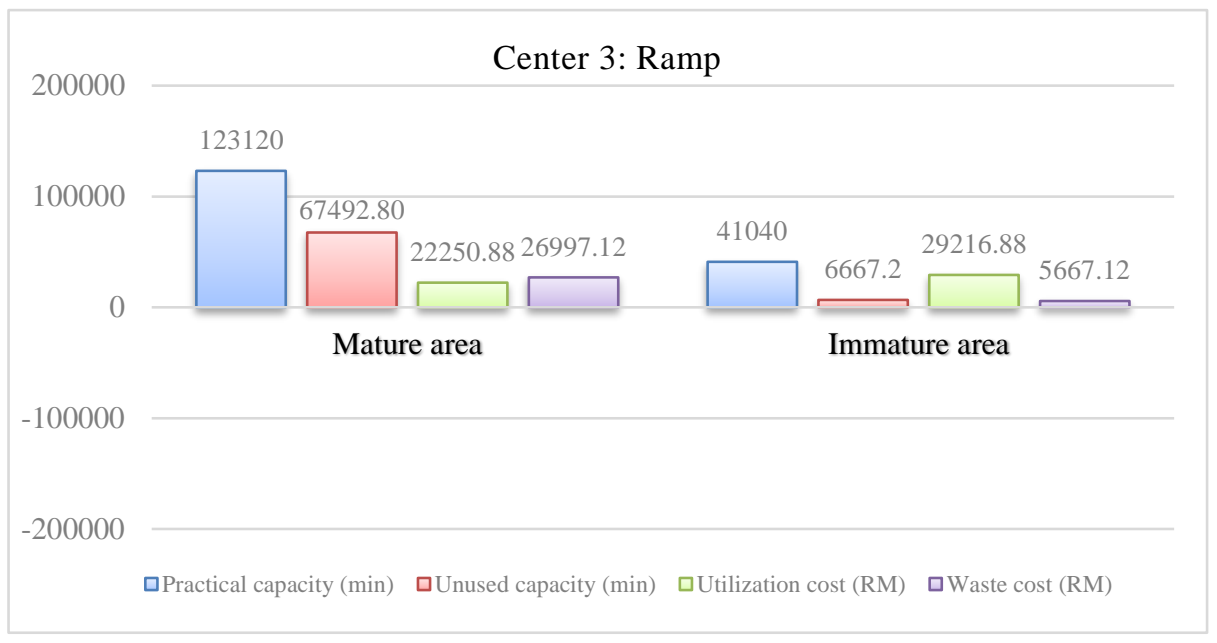

Figure 1. Used capacity and waste costs in ramp

\section{CONCLUSION}

In summary, it designed a time equation, capacity cost rate, used and unused capacity for ramp of palm oil plantations' mature and immature areas successfully. The manager therefore has a better overview on reducing operating costs based on a study of the consumption of the capacities to increase work capacity and reduce waste costs.

\section{ACKNOWLEDGEMENT}

The RDU1903105 supports this research entirely and the authors completely acknowledge University of Malaysia Pahang for the designated fund that makes this research possible.

\section{REFERENCES}

[1] J.V. Geibler, "Market-based Governance for Sustainability in Value Chains: Conditions for Successful Standard Setting in the Palm Oil Sector," J. Cleaner Production, vol 56, pp. 39-53, 2013.

[2] "DOSM", Department of Statistics Malaysia, Putrajaya., 2019

[3] M.A. Abdullah, B. C. Chew, and S. R. Hamid, "The Sustainable Service Management Factors in High Technology Transport Service Industry", Journal of Advanced Manufacturing Technology, pp. 101-113, 2017.

[4] R. Cooper, and R. S. Kaplan, "Profit Priorities from Activity-based Costing", Harv Bus Rev., vol. 6, no. 91, pp. 30-135, 1991.

[5] N. F. Zamrud, and M. Y. Abu, "Comparative Study: Activity based Costing and Time Driven Activity based Costing in Electronic Industry", Journal of Modern Manufacturing Systems and Technology, vol 4, no. 1, pp. 68-81, 2020.

[6] N. F. Zamrud, M. Y. Abu, N. N. N. M. Kamil, and F. I. M. Safeiee, "A Comparative Study of Product Costing by using Activity-Based Costing (ABC) and Time-Driven Activity-Based Costing (TDABC) Method", International Manufacturing Engineering Conference \& The Asia Pacific Conference on Manufacturing Systems, pp. 171-178, 2020.

[7] S. N. A. M. Zaini, C. W. Zheng, and M. Y. Abu, "Costing Structure Improvement using Activity based Costing in Palm Oil Plantation of Malaysia", Journal of Modern Manufacturing Systems and Technology, vol. 4, no. 1, pp. 95-109, 2020.

[8] G. Keel, C. Savage, M. Rafiq, and P. Mazzocato, "Time-Driven Activity-based Costing in Health Care: A Systematic Review of the Literature", Health Policy, vol. 121, no. 7, pp. 755-763, 2017.

[9] N. F. Zamrud, M. Y. Abu, N. N. N. M. Kamil, and F. L. M. Safeiee, "The Impact of Capacity Cost Rate and Time Equation of Time-Driven Activity-based Costing (TDABC) on Electric Component", International Manufacturing Engineering Conference \& The Asia Pacific Conference on Manufacturing Systems, pp. 81-87, 2020.

[10] N. F. A. Ghani, S. N. A. M. Zaini, and M. Y. Abu, "Assessment the Unused Capacity using Time Driven Activity based Costing in Automotive Manufacturing Industry", Journal of Modern Manufacturing Systems and Technology. vol. 4, no. 1, pp. 82-94, 2020.

[11] N. N. N. M. Kamil, M. Y. Abu, N. F. Zamrud, and F. L. M. Safeiee, "Analysis of Magnetic Component Manufacturing Cost through the Application of Time-Driven Activity-Based Costing", International Manufacturing Engineering Conference \& The Asia Pacific Conference on Manufacturing Systems, pp. 74-80, 2020.

[12] F. L. M. Safeiee, M. Y. Abu, N. N. N. M. Kamil, and N. F. Zamrud, "The Application of Time-Driven Activity based Costing System on Inductors in Electrics and Electronics Industry", International Manufacturing Engineering Conference \& The Asia Pacific Conference on Manufacturing Systems. pp. 88-95, 2020. 